\title{
Impact of habitat loss and fragmentation on reproduction, dispersal and species persistence for an endangered Chilean tree
}

\author{
Tonya A. Lander ${ }^{1}$ (D) Stephen A. Harris ${ }^{1} \cdot$ Patricia J. Cremona ${ }^{2} \cdot$ David H. Boshier $^{1}$
}

Received: 3 December 2018 / Accepted: 22 April 2019 / Published online: 30 April 2019

(c) The Author(s) 2019

\begin{abstract}
Survival of rare and endangered plant species following habitat loss and fragmentation is dependent upon in situ reproduction and population persistence, and establishment in new sites, so that stochastic, local extirpation does not lead to species extinction. Here we investigate if and how vegetative and sexual reproduction, propagule dispersal, and seedling establishment promote in situ persistence and establishment in new sites for the endangered, endemic Chilean tree Gomortega keule, in a landscape experiencing extensive habitat loss and fragmentation. Genetic analyses show G. keule reproduces vegetatively, producing large clone groups and providing a mechanism for long-term in situ persistence. Abundant seed set was observed, but seedling establishment was rare. At the single site where seedlings were observed, parentage analysis revealed seed dispersal over greater distances, and in a more aggregated pattern, than would be expected from gravity dispersal alone. We hypothesize that G. keule may represent a 'seed dispersal anachronism', wherein the native seed disperser has been lost and possibly replaced by domesticated cattle. The lack of seedling establishment at most sites raises concerns about the ability of existing populations to expand within existing habitat patches or establish at new locations. Globally, habitat loss and fragmentation, coupled with other environmental changes, pose a particular threat to rare species with small populations, because inbreeding and the loss of mutualists can lead to establishment failure and local extirpation. We propose that analysis of a plant's reproductive strategies as a whole, in its landscape context, is essential for effective species conservation.
\end{abstract}

Keywords Vegetative reproduction $\cdot$ Pollination $\cdot$ Seedling establishment $\cdot$ Seed dispersal anachronism $\cdot$ Chile $\cdot$ Habitat loss $\cdot$ Fragmentation $\cdot$ Endangered species

\section{Introduction}

According to the Millennium Ecosystem Assessment, $50-66 \%$ of terrestrial biomes have been changed and fragmented (http://www.maweb.org), leaving many species as small populations in spatially separated fragments. Survival of rare plant species following habitat loss and fragmentation is dependent upon in situ reproduction and population persistence, and establishment in new sites, so that stochastic, local extirpation does not lead to species extinction (Schurr et al. 2007). In situ persistence involves either vegetative reproduction or pollination, seed set and seedling

Tonya A. Lander

tonya.lander@plants.ox.ac.uk

1 Department of Plant Sciences, University of Oxford, South Parks Road, Oxford OX1 3RB, UK

2 IUCN Global Species Programme, David Attenborough Building, Pembroke Street, Cambridge CB2 3QZ, UK establishment; and establishment in new sites requires propagule dispersal. However, habitat loss and fragmentation are expected to change the quantity, quality and patterns of gene-flow among populations (Rymer et al. 2015; Young et al. 1996) and change the occurrence and extent of vegetative reproduction (Franceschinelli and Bawa 2000; van Kleunen et al. 2001), and species dispersal (Cheptou et al. 2017). Understanding how habitat loss and fragmentation change the frequency and type of species' reproduction and dispersal is essential for robust analyses of species' survival risk and conservation planning (Carrió et al. 2009; Evans et al. 2003; Pereira et al. 2004; Zeigler et al. 2013).

There is substantial variation in how plant species and plant-animal interactions respond to fragmentation (Brudvig et al. 2015). However, there are some established expectations about the relationships between habitat loss and fragmentation and vegetative reproduction, pollination, seed set, and seedling establishment. Vegetative reproduction of woody plants is common in both temperate 
and tropical forests, and is a common disturbance adaptation (Bellingham 2000). It is expected to minimize dependence on seedling recruitment, and to reduce the impacts of local disturbance, vulnerability to inbreeding, and loss of pollinators and dispersers, thus it is expected to play a central role in population persistence for some species following habitat loss and fragmentation (Bond and Midgley 2001). Importantly, vegetative reproduction does not generally facilitate establishment in new sites, or provide genetic recombination to support evolution and adaptation, which are likely to be critical for species survival given on-going environmental change.

Pollination, seed set and seedling establishment are the key steps in establishment of new individuals via sexual reproduction, and failure of any of these steps can threaten species persistence. Recent syntheses suggest that although in theory fragmentation may either increase (e.g. Lander et al. 2010; White et al. 2002) or decrease gene flow between populations (e.g. Vranckx et al. 2012), either of which may reduce effective pollination, seed set and seedling establishment; empirical observations for forest tree species have found changes to gene flow that are more nuanced than simply increases or decreases (for example, increased short-distance pollination as well as an increase in long-distance seed or pollen dispersal for the same species in a fragmented landscape) (Lowe et al. 2015). This complexity is due in part to the fact that forest tree species have attributes which can ameliorate the population genetic consequences of habitat fragmentation. Empirical studies of post-fragmentation gene flow have found long distance gene flow via pollen and/or seed, which avoids genetic isolation; the presence of overlapping generations, which slows the loss of genetic diversity; and flexible mating systems, which allow the production of progeny through self-fertilization (Lowe et al. 2015). If habitat fragmentation does result in reduced pollen and propagule movement between forest fragments, this may lead to increased spatial genetic structure and reduced local genetic variation and adaptive potential due to increased inbreeding and genetic drift (Reed and Frankham 2003; Sork et al. 2002). Increased inbreeding can also reduce seed set and offspring performance, which in turn can result in reduced population size and population viability (Byrne et al. 2007; Husband and Schemske 1996; Lowe et al. 2005; Rymer et al. 2015; Vranckx et al. 2012; Wright et al. 2008). Increased gene flow following habitat fragmentation can also have deleterious consequences, such as reduced local adaptation (Lenormand 2002; but see Tigano and Friesen 2016). In summary, trees may or may not show increases or decreases in gene flow following habitat fragmentation, depending on species and context, and if either increased or decreased gene flow occurs it may reduce reproductive success and the probability of population persistence.

The expectations about the relationship between habitat loss and fragmentation and propagule dispersal are similarly complex. Long-distance propagule dispersal, although only a small proportion of all propagule dispersal, is expected to be disproportionately important for population and metapopulation dynamics, range expansion, and migration (Cain et al. 2000; Hanski 1998; Nathan and Muller-Landau 2000). Depending on the mechanism of propagule dispersal and the specific changes to the landscape, habitat loss and fragmentation may either increase or decrease the likelihood of propagule dispersal and the distances over which it occurs. For example, both wind-dispersed and animal-dispersed seeds may disperse shorter or longer distances following the loss of native vegetation, which can positively or negatively impact population and meta-population dynamics (Damschen et al. 2014; Herrera and Garcia 2010).

In this study we investigate how habitat loss and fragmentation affect reproduction and dispersal, and the probability of population persistence and expansion, for the endangered tree Gomortega keule Ruíz \& Pavón (Gomortegaceae), endemic to the Central Chile Biodiversity Hotspot (CCBH). In the $\mathrm{CCBH} 70 \%$ of the area has been converted from native ecosystems to human land uses. This loss of native habitat poses a serious threat to the species dependant on those ecosystems, including 1605 plant species, of which 173 are endemic and/or threatened (Brooks et al. 2002; Myers et al. 2000). Gomortega keule exists as small, scattered stands, and is categorized as Endangered in the IUCN Red List on the basis of an estimated population reduction of $\geq 70 \%$, linked to logging and forest management activities, fire and agricultural encroachment (González 1998; IUCN 2012; Oldfield et al. 1998). Previous authors have reported that G. keule's reproduction is characterized by suspected, but unconfirmed, vegetative reproduction and abundant seed set, but that seedling establishment is extremely rare (Lander et al. 2010; Villegas et al. 2003). As far as we are aware, there are no published data on propagule dispersal in $G$. keule.

We address the following questions to assess specific threats to G. keule population persistence and expansion, and suggest potential management interventions to mitigate those threats.

\section{Vegetative reproduction}

\section{Question 1 (Q1) Does G. keule reproduce vegetatively?}

Because G. keule coppices readily, and individuals sometimes occur as rings of saplings around older trees, we hypothesized that $G$. keule could reproduce vegetatively 
and that this may provide a means of in situ population persistence.

\section{Pollination, seed set and seedling establishment}

Question 2 (Q2): Is there evidence of selection against seed produced by self-fertilization at the seedling establishment phase?

As there were seeds but not seedlings at most G. keule study sites, we hypothesized that high levels of self-fertilization or inbreeding could have resulted in seed inviability, or seedling mortality.

\section{Propagule dispersal}

Question 3 (Q3) How far do G. keule seeds disperse and establish into seedlings?

Because Gomortega keule's fruit are large, heavy drupes with fleshy mesocarp, they appear to be adapted for vertebrate dispersal (Fig. 1). We hypothesized that we would observe more frequent long-distance dispersal, and more aggregated seedling establishment, than would occur with gravity dispersal alone.

\section{Materials and methods}

\section{Study species}

Gomortega keule is a self-fertile diploid $(2 \mathrm{n}=42)$ Chilean tree in the monotypic family Gomortegaceae (Goldblatt 1976; Lander et al. 2010; Soltis and Soltis 2004). The global distribution of this species is limited to a strip $70 \mathrm{~km}$ wide and $250 \mathrm{~km}$ long in the Central Chile Biodiversity Hotspot (Myers 1990; San Martin and Sanchez 1999) (Fig. 2). Previous analysis of the study populations of G. keule found significant within-site spatial genetic structure up to $100 \mathrm{~m}$ and low genetic differentiation between populations (Lander et al. 2010). Widespread forest clearance in the region has produced a landscape where G. keule is mainly present as small stands in spatially separated fragments of native forest and as single trees in subsistence agriculture areas (San Martín and Donoso 1995). The species is listed as Endangered by the IUCN due to the small global population, restricted global distribution, and threat from habitat loss (González 1998). As far as we are aware, rates of land-use change and forest loss in the study area have not been quantified recently. However, continuous loss of forest cover has been documented for the years between 1975 and 2008 in the region of Chile north of the study area (Schulz et al. 2010), and between 1989 and 2003 in the region east of the study area (Altamirano and Lara 2010). We expect this pattern of dwindling forest habitat to be the same in the study area, and for this to continue to pose a threat to G. keule.

\section{Study sites and tree and site characteristics}

Twenty-six study sites were identified in the Tregualemu area on the border between the Maule and Bío-Bío Regions of Chile (see study site description Lander et al. 2010). These study sites contain all of the G. keule individuals that were found during two intensive field surveys of a $\sim 10 \mathrm{~km} \times 10 \mathrm{~km}$ study area (February-April 2005 and July-August 2006). A 'site' was defined either as a stand of G. keule trees in which no individual was separated from the group by more than $200 \mathrm{~m}$, or as a single tree ("Soltero") separated by more than $200 \mathrm{~m}$ from other G. keule individuals. Each tree was individually numbered and the geographical location recorded. Once clone groups were identified, for each clone group the point location used for analyses was the centre point of the convex hull of the geographical point data for the group of ramets (calculated in ArcMap 10.2.1 (ESRI)). Population size was defined as all adult trees at a site, with clone groups counted as one individual. In total 676 adult trees were sampled from the 26 study sites (Table 1).

For each tree, leaf samples were collected for genetic analyses or, if leaves were inaccessible, cambium samples

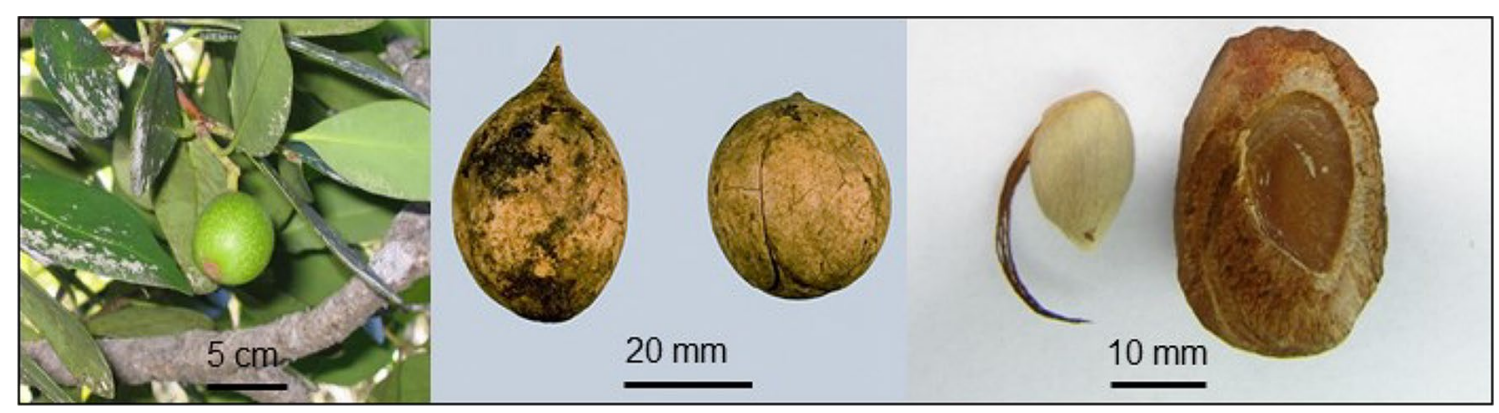

Fig. 1 Unripe fruit, endocarp and seed of G. keule 


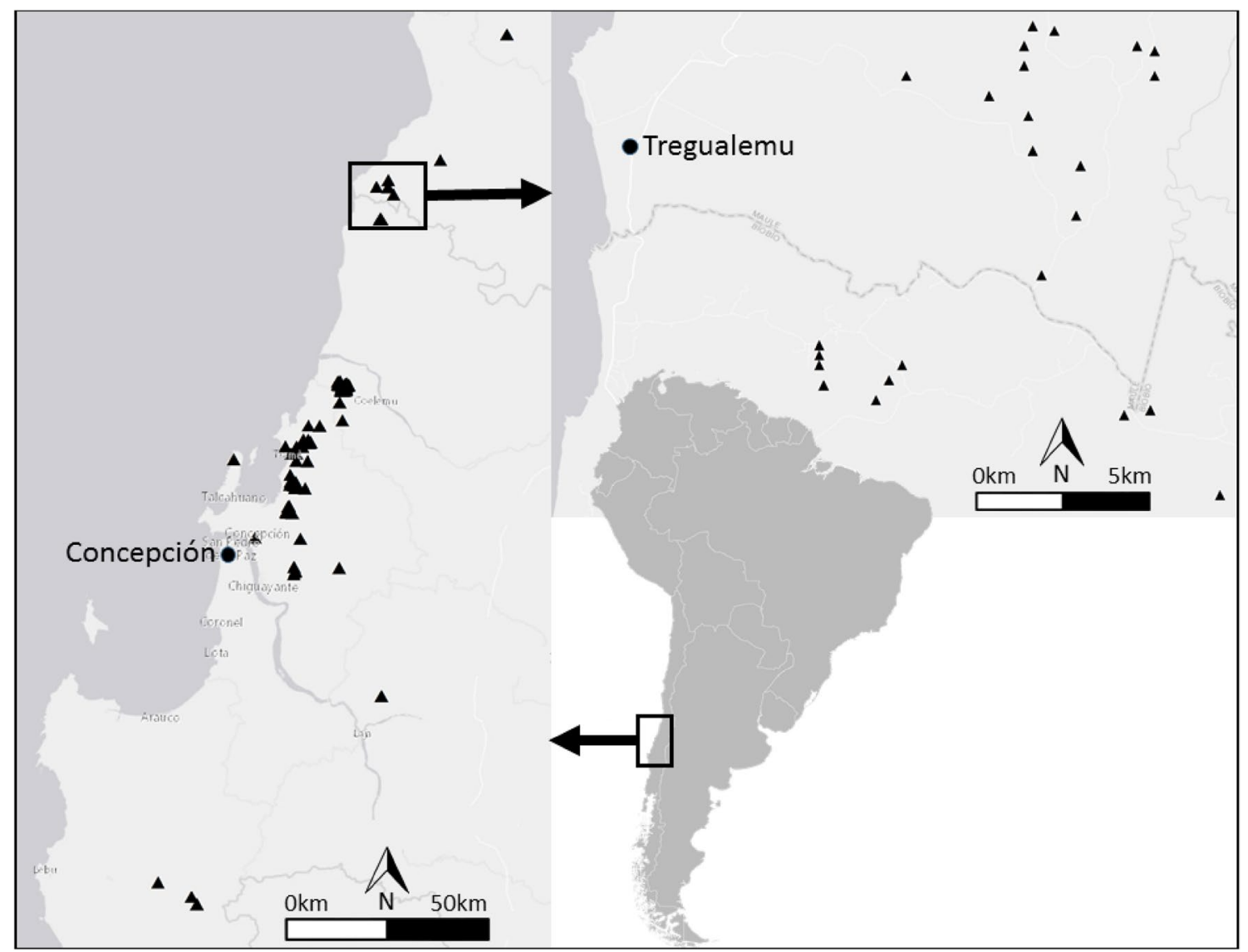

Fig. 2 Bottom right: The rectangle indicates the global distribution of Gomortega keule (Maule and Bío-Bío Regions, Chile). Left: Known populations of G. keule (Hechenleitner et al. 2005), the rectangle

were collected. Leaf and cambium samples were dried with silica gel crystals. Trees producing fruit were identified at 18 of the 26 study sites (Table 1). Thirty-five fruits were collected from each fruiting tree. If fewer than 35 fruits were present on the tree all available fruit were collected. The mesocarp was removed from each fruit and the woody endocarp containing the seeds dried with silica gel crystals. All seeds from each endocarp were used for genetic analyses. During field surveys in both years, and in accordance with previous observations (e.g. Villegas et al. 2003), seedlings were found at only two of the 26 study sites: one seedling at the Reserva Nacional Los Queules, and 99 seedlings at Quiles Alto. Leaf samples were collected from all seedlings, dried in silica gel crystals, and used for genetic analyses.

Tree size and canopy exposure are expected to affect the outcrossing rate and seed dispersal distance (Burczyk et al. 1996; Niinemets 2007). For each tree in the study, tree diameter at breast height (dbh at $1.3 \mathrm{~m}$ above the ground) was measured for all individuals. When trees had multiple stems, all stems were measured and the weighted mean dbh calculated as the square root of the sum of the squares of indicates the study area. Top right: The centre points of the 26 study sites ( 24 shown due to point overlap)

the dbhs. For analyses where clone groups were counted as one adult, the dbh was the weighted mean dbh of the ramets in the clone group. Tree canopy exposure was categorized as: (1) lower understorey; (2) upper understorey; (3) lower canopy; (4) canopy; (5) emergent or (6) alone in an open area, according to the Dawkins crown position classification system (Synnott 1979).

A linear mixed effects model (lme, Pinheiro et al. 2018) was used to assess the ability of local population size (number of trees in the study site), canopy exposure, and dbh to predict the proportion of self-fertilized seeds per tree. No interactions between explanatory variables were included. Study site was included in the model as a random effect. Model selection was conducted using stepAIC (Venables and Ripley 2002). The stepAIC procedure performs stepwise variable selection by adding or removing predictors to produce a model that minimizes the Akaike's Information Criterion (AIC), providing a parsimonious tradeoff between model fit and model complexity. 
Table 1 The 26 study sites in Maule/Bío -Bío, Chile

\begin{tabular}{|c|c|c|c|c|c|c|c|c|}
\hline Site & No of genets ${ }^{\mathrm{a}}$ & No of ramets ${ }^{b}$ & $\%$ Reduction $^{\mathrm{c}}$ & $\begin{array}{l}\text { No of } \\
\text { clone } \\
\text { groups }\end{array}$ & $\begin{array}{l}\text { Trees that self- } \\
\text { fertilized }(\%)\end{array}$ & $\begin{array}{l}\text { Seeds } \\
\text { (seedlings) } \\
\text { collected }\end{array}$ & $\begin{array}{l}\text { Latitude }^{\mathrm{d}} \\
\text { (dd) South }\end{array}$ & $\begin{array}{l}\text { Longitude } \\
\text { (dd) West }\end{array}$ \\
\hline La Reserva & 176 & 195 & 10 & 2 & $16(9.1)$ & $196(1)$ & 35.983 & 72.689 \\
\hline Ralbun & 92 & 147 & 37 & 18 & $12(13.0)$ & 218 & 36.063 & 72.636 \\
\hline Reserva Norte & 32 & 41 & 22 & 6 & $4(12.5)$ & 96 & 35.977 & 72.681 \\
\hline Bajo Pino 1 & 30 & 38 & 21 & 5 & 0 & 1 & 35.973 & 72.681 \\
\hline El Limite & 22 & 50 & 56 & 6 & $3(13.6)$ & 30 & 35.994 & 72.679 \\
\hline Quiles Alto & 22 & 22 & 0 & 0 & $10(45.5)$ & 189 (99) & 36.037 & 72.709 \\
\hline La Puente & 20 & 21 & 5 & 1 & $6(30.0)$ & 69 & 35.973 & 72.655 \\
\hline Bajo Pino 2 & 18 & 36 & 50 & 1 & 0 & 0 & 35.969 & 72.679 \\
\hline Copiulemu Hijuela 5 & 17 & 40 & 58 & 4 & $6(35.3)$ & 65 & 35.997 & 72.668 \\
\hline Fragmento Tres & 16 & 18 & 11 & 1 & $3(18.8)$ & 39 & 35.979 & 72.708 \\
\hline Limite Ciruelillo & 11 & 13 & 15 & 2 & $1(9.1)$ & 1 & 35.979 & 72.651 \\
\hline El Parron & 10 & 11 & 9 & 1 & $1(10.0)$ & 10 & 36.047 & 72.658 \\
\hline Picoton & 9 & 20 & 55 & 1 & 0 & 0 & 36.041 & 72.727 \\
\hline Ramadillos & 7 & 8 & 13 & 1 & 0 & 10 & 36.007 & 72.669 \\
\hline Bajo Pino Nuevo & 4 & 4 & 0 & 0 & $1(25.0)$ & 2 & 35.987 & 72.680 \\
\hline Pareja 0014 & 2 & 2 & 0 & 0 & 0 & 0 & 35.969 & 72.679 \\
\hline Soltero 0013 & 1 & 1 & - & - & 0 & 0 & 35.970 & 72.674 \\
\hline Soltero 0068 & 1 & 1 & - & - & $1(100)$ & 18 & 35.974 & 72.651 \\
\hline Soltero 0126 & 1 & 1 & - & - & $1(100)$ & 37 & 35.987 & 72.680 \\
\hline Soltero 0186 & 1 & 1 & - & - & 0 & 4 & 36.044 & 72.715 \\
\hline Soltero 0187 & 1 & 1 & - & - & $1(100)$ & 33 & 36.040 & 72.712 \\
\hline Soltero 0198 & 1 & 1 & - & - & 0 & 0 & 36.037 & 72.728 \\
\hline Soltero 0199 & 1 & 1 & - & - & 0 & 1 & 36.035 & 72.728 \\
\hline Soltero 0200 & 1 & 1 & - & - & 0 & 0 & 36.033 & 72.728 \\
\hline Soltero 0262 & 1 & 1 & - & - & 0 & 0 & 36.019 & 72.677 \\
\hline Soltero 0274 & 1 & 1 & - & - & 0 & 0 & 36.046 & 72.652 \\
\hline Total & 498 & 676 & 26 & 49 & 66 & $1019(100)$ & & \\
\hline
\end{tabular}

${ }^{a}$ Genets are genetically distinct adult trees, where one clone group is counted as one adult, irrespective of the number of ramets in the clone group

${ }^{\mathrm{b}}$ Ramets are physically distinct adult trees which may be members of a clone group. This is the value if all ramets are counted as separate individuals

${ }^{c}$ The percent reduction in effective population size when the count of adult individuals is based on genets rather than ramets

${ }^{\mathrm{d}}$ The coordinates are for the centre of the convex hull of each site

\section{Genetic analyses}

To determine whether $G$. keule reproduces vegetatively (Q1), whether there is evidence of selection against offspring produced by self-fertilization (Q2), and how far seeds disperse (Q3), the following genetic analyses were undertaken.

DNA was extracted from the adult leaves or cambium, seedling leaves, and seed samples, and all samples were genotyped using six nuclear single sequence repeat (SSR) markers (Gk1, Gk6, Gk30, Gk31, Gk39, and Gk44) (see protocols in Lander et al. 2007). For these SSR markers the probability of identity using GENALEX v.6.1 (Peakall and Smouse 2006) was found to be $1.96 \times 10^{-7}$, indicating that the probability that two unrelated individuals will have the same multilocus genotype is extremely small. There was no pattern of homozygote-homozygote mismatches in known parent-offspring relationships, and analysis in MICROCHECKER (Oosterhout et al. 2004) showed there were no null alleles present. Using this SSR data, trees that were found to have identical genotypes were considered ramets of a single clone. In subsequent paternity and parentage analyses each clone group was included as a single tree, regardless of the number of ramets identified. These data were used to address Q1.

Reproduction through bi-parental inbreeding, not including self-fertilization, was calculated in MLTR (Ritland 2002) as $t_{m}-t_{s}$, where $t_{m}$ is the multilocus outcrossing rate and $t_{s}$ is the rate of crossing between unrelated individuals. The 
inbreeding estimate was made for the five study sites with four or more progeny arrays of at least ten seeds (Copiulemu Hijuela 5, La Reserva, Quiles Alto, Ralbun and Reserva Norte). Reproduction through bi-parental inbreeding for the adults, seedlings and seeds at the Quiles Alto site was calculated in GenAlEx v. 6.1. The inbreeding data were used to address Q2.

To identify seeds and seedlings produced by self-fertilization, and to characterize effective dispersal (seedling establishment distances from parents (e.g. Hardesty et al. 2006), paternity and parentage analyses were conducted for all seeds and seedlings in CERVUS (Kalinowski et al. 2007). The probability estimate of paternity and parentage exclusion with the six SSR markers was 0.999 (calculated in GenAlEx v. 6.1), indicating a high information content for parentage-based analyses of gene-flow. Paternity analysis was undertaken for the seed samples because the seeds were collected from their maternal trees and so it was only necessary to identify the pollen-donor tree. Parentage analysis was undertaken for the seedlings because neither the maternal nor the pollen-donor tree was known. Following Bacles et al. (2006), of the two parent trees assigned to each seedling, the closest one (spatially) was assumed to be the maternal tree. These data were used to address Q2 and Q3.

If there were selection against inbred seed at the seedling establishment phase, we would expect lower heterozygosity in seeds compared to seedlings. To assess the difference in heterozygosity between seeds and seedlings at Quiles Alto, the only study site where seedlings were found, heterozygosity values were calculated in GDA (Lewis and Zaykin 2002). The heterozygosity values were arcsine square-root transformed to make the distributions more closely approximate the normal distribution and to equalize sample variances (Archie 1985). Heterozygosity differences between the cohorts were then tested using the paired student's $t$ test. These data were used to address Q2.

To estimate seed dispersal distance and identify distance outliers or spatial aggregation that might indicate vertebrate dispersal, the distance and direction to the nearest adult tree was measured in centimetres and degrees using a tape measure and compass for each of the 99 seedlings at the Quiles Alto study site. The seedlings were mapped with the adults in ArcMap 10.2.1 to calculate seedling-adult and seedlingparent distances. To further investigate the possibility of vertebrate dispersal, an estimate of seedling aggregation, taken as an indication of non-random seed dispersal, was calculated. Following Hardesty et al. (2006), Ripley's K function minus $\pi r^{2}\left(K(r)-\pi r^{2}\right)$ was used in the "spatstat" package in R, incorporating an edge correction (Baddeley et al. 2015), to test for spatial aggregation of adults and seedlings. Because $\pi r^{2}$ is the expected value of Ripley's function for random spatial distribution (Poisson distribution), $\mathrm{K}(\mathrm{r})-\pi \mathrm{r}^{2}>0$ indicates aggregation and $\mathrm{K}(\mathrm{r})-\pi \mathrm{r}^{2}<0$ indicates a regular distribution. For both seedlings and adults the observed distribution was compared with the theoretical expectation of the Poisson distribution based on 500 random simulations. These data were used to address Q3.

\section{Results}

\section{Vegetative reproduction}

The genetic analyses allowed us to address Q1 (Does $G$. keule reproduce vegetatively). Of the 676 trees sampled there were 498 genetically distinct individuals, and $26 \%$ of the sampled trees had at least one genetically identical neighbour (Table 1). Clonal groups were identified at $50 \%$ of the 26 study sites, and ranged in size from 2 to 19 ramets, with a mean of 3.5 ramets per clone. In total 49 clones were identified. The clone with the largest diameter was at the Ralbun site, with a maximum convex hull diameter of $87 \mathrm{~m}$ among the 12 ramets.

\section{Pollination, seed set and seedling establishment}

Genetic analyses allowed us to address Q2, whether there is selection against $G$. keule seeds produced by self-fertilization at the seedling establishment phase. For the sites analyzed, the average value of biparental inbreeding calculated in MLTR was 0.098, and in GDA was 0.086 . The inbreeding rate at Quiles Alto, where the majority of seedlings were found, was higher than the average inbreeding rate according to the MLTR analysis, but not according to the GDA analysis (Table 2). The paternity analysis revealed that $25 \%$ of all seeds, whether produced by clones or not, were the result of self-fertilization (Table 3). There was no significant difference between the number of seeds produced through self-fertilization by trees that were members of clone groups compared to trees that were not members of clone groups $\left(\chi^{2}(\mathrm{df}=1), \mathrm{p}=0.88\right)$ (Table 3$)$. Single trees separated by more than $200 \mathrm{~m}$ from other $G$. keule individuals ('Solteros') produced significantly more seeds by self-fertilization than did other trees $\left(\chi^{2}(\mathrm{df}=1)\right.$, $\mathrm{p} \ll 0.001$ ) (Table 3). Trees producing seeds through selffertilization as well as outcrossing produced more seed than trees that only produced seed through outcrossing (mean seeds $=13.15, \sigma=11.38$; mean seeds $=3.05$, $\sigma=3.81$ respectively; t-test $\mathrm{p}<0.001$ ).

In the linear mixed effects model, the proportion of selffertilized seeds per tree was not explained by the number of G. keule trees in the forest fragment, canopy exposure, or dbh. P-values were not significant for the three explanatory variables in the model, as fit by maximum likelihood. Moreover, in the forward and backwards stepwise model 
Table 2 Biparental inbreeding values for the five sites with four or more progeny arrays of at least ten seeds

\begin{tabular}{|c|c|c|c|c|}
\hline Site & GDA, $\mathrm{F}_{\mathrm{IS}}$ & $\operatorname{MLTR}\left(\mathrm{t}_{\mathrm{m}}-\mathrm{t}_{\mathrm{s}}\right)$ & $\begin{array}{l}\text { No. progeny arrays with } \geq 10 \\
\text { seeds }\end{array}$ & $\begin{array}{l}\text { Average seeds/ } \\
\text { progeny array }\end{array}$ \\
\hline Copiulemu Hijuela 5 & 0.09 & 0.077 & 4 & 13.3 \\
\hline La Reserva & 0.10 & 0.084 & 5 & 22.2 \\
\hline Ralbun & 0.09 & 0.089 & 7 & 22.4 \\
\hline Quiles Alto (QA) & 0.07 & 0.112 & 9 & 27.9 \\
\hline \multirow[t]{2}{*}{ Reserva Norte } & 0.08 & 0.130 & 4 & 15.8 \\
\hline & GenAlEx, & & & \\
\hline QA all & 0.095 & & & \\
\hline QA adults & 0.032 & & & \\
\hline QA seedlings & 0.068 & & & \\
\hline QA seeds & 0.186 & & & \\
\hline
\end{tabular}

Table 3 Seeds and seedlings produced through selffertilization

\begin{tabular}{lrr}
\hline & Total & $\begin{array}{l}\text { Number produced } \\
\text { through self-fertilization } \\
(\%)\end{array}$ \\
\hline All seeds assigned parentage & 1019 & $257(25.2)$ \\
Seeds produced by clone groups & 77 & $20(25.9)$ \\
Seeds not produced by clone groups & 942 & $237(25.2)$ \\
Seeds produced by single trees ('Solteros', $\mathrm{n}=5$ trees) & 92 & $52(56.5)$ \\
Seeds not produced by single trees & 927 & $205(22.1)$ \\
Quiles Alto: seeds not produced by clone groups* & 189 & $48(22.2)$ \\
All seedlings assigned parentage & 100 & $18(18.0)$ \\
\hline
\end{tabular}

*No clone groups were identified at Quiles Alto

Table 4 Results of the linear mixed effects model fit by maximum likelihood where the number of G. keule trees in the forest fragment (popsize), tree dbh (dbh), and canopy exposure (canopy) were tested as fixed effects for the proportion of self-fertilized seeds per tree (selfed_seeds)

\begin{tabular}{|c|c|c|c|c|c|}
\hline AIC & & & & & $\log \mathrm{Lik}$ \\
\hline 74.75 & & & & & -31.37 \\
\hline & & & & & Residual \\
\hline StdDev & & & & & 0.299 \\
\hline & Value & Std. Error & $\mathrm{DF}$ & t-value & p-value \\
\hline (Intercept) & 0.234 & 0.077 & 124 & 3.031 & 0.003 \\
\hline popsize & 0.001 & 0.001 & 16 & 0.705 & 0.491 \\
\hline $\mathrm{dbh}$ & 0.000 & 0.001 & 124 & 0.026 & 0.979 \\
\hline canopy & -0.014 & 0.014 & 124 & -1.004 & 0.318 \\
\hline Model & & & & & AIC \\
\hline selfed_seed & + canopy & & & & 74.75 \\
\hline & & & & & 72.75 \\
\hline selfed_seed & & & & & 71.02 \\
\hline selfed_seed & & & & & 69.98 \\
\hline
\end{tabular}

Site was included in the model as a random effect. Model selection was conducted using stepwise variable selection by adding or removing predictors to produce a model that minimizes the Akaike's Information Criterion (AIC) 
selection, AIC was lowest for the model with none of the three explanatory variables (Table 4 ).

Q2 (Is there selection against seed produced by selffertilization at the seedling establishment phase?) could only be addressed for the Quiles Alto site, where 99 of 100 seedlings were found. There was no significant difference between the percentage of seeds and seedlings produced through self-fertilization at Quiles Alto $\left(\chi^{2}(\mathrm{df}=1)\right.$, $\mathrm{p}=0.40$ ) (Table 3). There was also no significant difference in mean heterozygosity or homozygosity, or the effective number of alleles between adults, seeds and seedlings at Quiles Alto (Table 5). However the GenAlEx analysis found a higher inbreeding coefficient $\left(\mathrm{F}_{\mathrm{IS}}\right)$ among the seeds than the seedlings or adults at Quiles Alto (Table 2).

\section{Propagule dispersal}

In addressing Q3 (Do G. keule seeds disperse? If so, how far?), we focused on effective seed dispersal by investigating the spatial relationship between maternal trees and their established seedlings at the Quiles Alto site. The distance between each seedling and its maternal tree was significantly greater than the distance between that seedling and the nearest adult tree (mean $=9.5 \pm 10.6 \mathrm{~m}$ and $3.5 \pm 2.4 \mathrm{~m}$ respectively; paired t-test $\mathrm{p} \ll 0.001$ ), indicating that most seedlings were found nearest to adult trees that were not their maternal trees. The mean seedling-mother distance at Quiles Alto was $49.6 \pm 222.9 \mathrm{~m}$; however, this decreased to $9.5 \pm 10.6 \mathrm{~m}$ after removing three outlying seed dispersal events (396.7, 402.6, and $1673.5 \mathrm{~m}$ ). Seed dispersal distance was positively correlated with maternal tree $\mathrm{dbh}(\mathrm{r}=0.31$, $\mathrm{n}=98, \mathrm{p}=0.002$ ). All adult trees at the Quiles Alto site were assigned a canopy exposure value of 3 , so it was not possible to assess the relationship between canopy exposure and dispersal distance. A Ripley's K analysis found that both seedlings and adults were significantly more aggregated than the theoretical expectation (Fig. 3). The seedlings in particular were aggregated in six small groups.
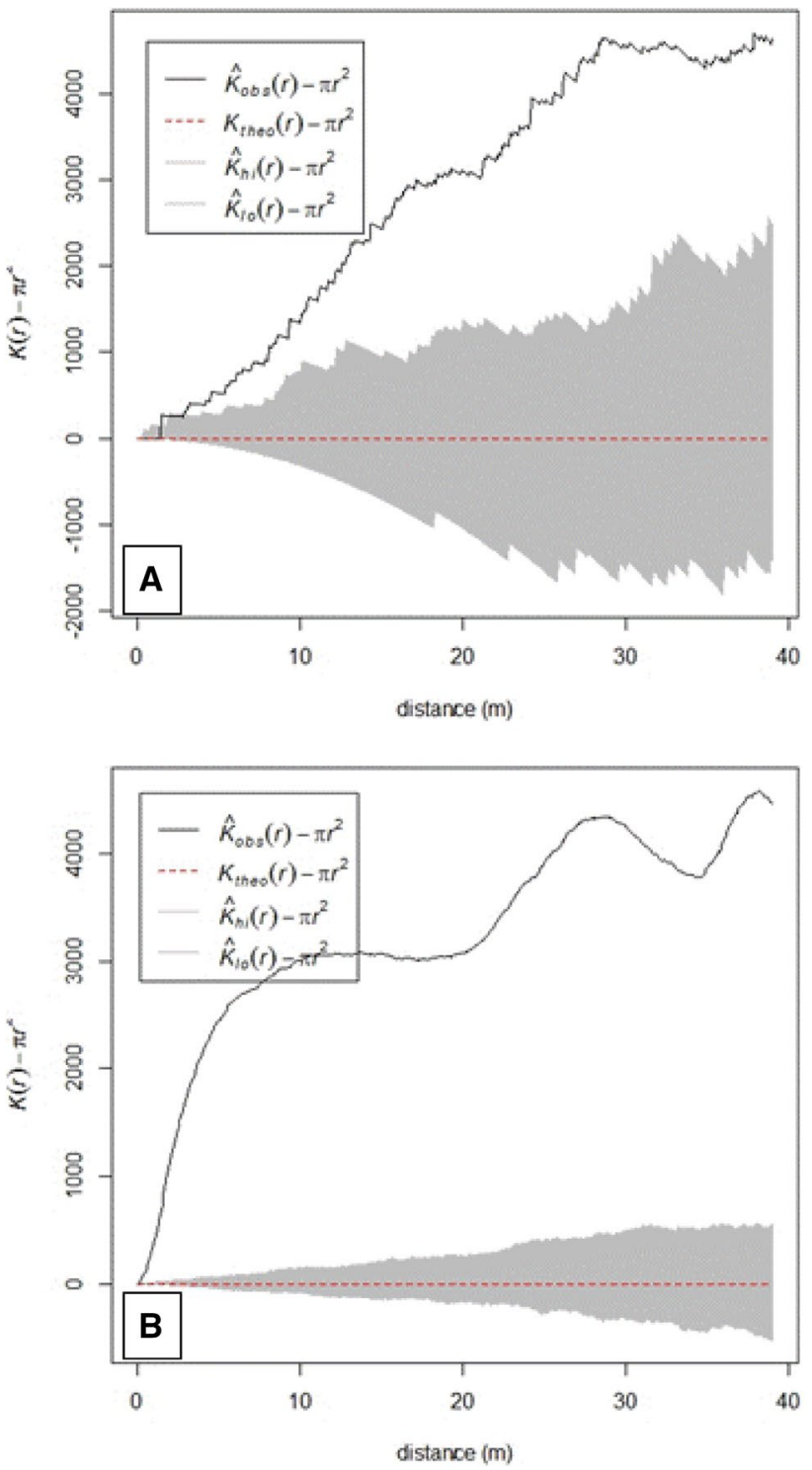

Fig. 3 Ripley's $\mathrm{K}$ minus $\pi \mathrm{r}^{2}$ for $\mathbf{a}$ adults and $\mathbf{b}$ seedlings at Quiles Alto. $K(r)-\pi r^{2}>0$ indicates spatial aggregation and $K(r)-\pi r^{2}<0$ indicates a regular distribution. Both seedlings and adults were significantly more spatially aggregated than the theoretical expectation of a Poisson distribution
Table 5 Mean heterozygosity (He), homozygosity (Ho), number of alleles $(\mathrm{Na})$, and effective number of alleles $(\mathrm{Ne})$ for all sampled adults and seeds, and adults, seeds and seedlings at the Quiles Alto (QA) study site

\begin{tabular}{lllll}
\hline & He (se) & Ho (se) & Na (se) & Ne (se) \\
\hline All adults & $0.764(0.044)$ & $0.669(0.077)$ & $14.667(1.282)$ & $4.961(0.828)$ \\
All seeds & $0.760(0.044)$ & $0.552(0.071)$ & $16.167(1.470)$ & $4.773(0.698)$ \\
QA adults & $0.718(0.058)$ & $0.695(0.117)$ & $7.500(1.500)$ & $4.488(0.944)$ \\
QA seeds & $0.694(0.073)$ & $0.565(0.083)$ & $10.833(1.167)$ & $4.285(0.956)$ \\
QA seedlings & $0.635(0.074)$ & $0.592(0.071)$ & $7.667(1.256)$ & $3.344(0.656)$ \\
\hline
\end{tabular}

99 of the 100 seedlings found during the study were at Quiles Alto 


\section{Discussion}

We have used G. keule as a case study of how habitat loss and fragmentation may impact reproduction and dispersal of a rare and endangered plant species. To do this, it has been necessary to characterize the reproductive strategies and propagule dispersal of G. keule, which had not been systematically investigated previously. Genetic analyses indicate that $G$. keule reproduces vegetatively, in some cases establishing large groups of clonal individuals. G. keule produces seeds through self-fertilization, inbreeding and outcrossing, and there was not conclusive evidence of selection against seeds resulting from self-fertilization or inbreeding at the seedling establishment phase. The seedlings that do exist appear to be the result of seed dispersal at greater distances, and in a more aggregated pattern, than would be expected from gravity dispersal alone. These reproductive and dispersal strategies together constitute the means by which $G$. keule can maintain current populations and establish new populations in a landscape experiencing habitat loss and fragmentation.

Gomortega keule's vegetative reproduction provides a means of long-term persistence in situ. Individual genets may survive indefinitely as clone groups, and each additional ramet adds to the overall fitness of the genet through survivorship, seed production, and subsequent ramet production (Eckert 2002). This strategy may be especially important for species persistence because the study area experiences regular environmental disturbances, such as storms, from which $G$. keule can recover by root-sprouting.

Although vegetative reproduction is a useful strategy, long-term survival of endangered plant species is thought to require successful sexual reproduction and generation turnover, even when there is successful vegetative reproduction (Aronne 2017). Moreover, Douhovnikoff et al. (2004) suggests the underlying assumptions behind many methods of genetic conservation management need to be reassessed when managing species that can reproduce vegetatively. Most importantly, without genetic analysis it is impossible to determine the effective population size. For the sixteen study sites with more than one tree, the reduction in population size from stem census (ramets) to effective population size (genets) ranged from 0 to $58 \%$, with a mean of $23 \%$ (Table 1). A reduction in effective population size of this magnitude could have an important impact on assessment of the need for genetic conservation action for a given population. However, Lander et al. (2010) found that these patches of $G$. keule are not genetically isolated from each other. This suggests that the delineation of populations based on spatial aggregation would be overly conservative and that the effective population size is actually larger than appears based on traditional, spatial delineation of the populations.
The fact that the effective breeding population extends beyond the boundaries of the individual study sites may explain the low rate of biparental inbreeding (0.098) and the lack of a significant difference in allelic diversity between the adult and seed samples (Table 5). However, G. keule does produce a large proportion of seeds through self-fertilization (25\%). Self-fertilization is generally considered an extreme form of inbreeding, and carries the same risks of reduced seed set, offspring performance and population size, resulting in increased local extinction risk. However, self-fertilization can also be a valuable strategy if non-self pollen is limiting and inbred progeny have a chance of survival (Lloyd 1992). Self-fertilization in G. keule cannot be explained by pollinator limitation because self-fertilization is through insect-mediated geitonogamy (Lander et al. 2009). Self-fertilization was also not explained by local population size, canopy exposure, or dbh. This means that there is not strong evidence that standard forest management interventions that would be expected to reduce rates of self-fertilization (e.g. enrichment planting to increase local population size, halo thinning to increase canopy exposure, or management to enhance pollinator populations) would significantly reduce self-fertilization for this species. In summary, G. kaule has a functioning strategy for sexual reproduction, but the high rates of self-fertilization may be a cause for conservation concern, and management interventions to reduce self-fertilization rates are not immediately obvious.

Our hypothesis that the presence of seeds but absence of seedlings could be the result of selection against seeds that were the result of self-fertilization was not strongly supported. At Quiles Alto, where most seedlings were found, the parentage analysis identified similar proportions of seeds and seedlings that were the result of self-fertilization $(22 \%$ and $18 \%$ respectively, Table 3 ), suggesting little or no selection against seeds produced through self-fertilization during seed germination and seedling establishment. However the GenAlEx analysis found higher $\mathrm{F}_{\mathrm{IS}}$ among the seeds than the seedlings or adults at Quiles Alto, suggesting there may be selection against inbred individuals at the seed germination stage which was not identified in our paternity analysis. With these conflicting results we cannot determine whether self-fertilization and inbreeding might present a problem for G. keule population persistence or expansion via seedling establishment. In addition, the small number of seedlings and the lack of any seedling establishment at all but two sites, make it difficult to draw firm conclusions.

From a management perspective, it is worth noting that single trees produced seeds through self-fertilization more than twice as frequently as non-single trees $(56.5 \%$ and $22.1 \%$ respectively, Table 3 ). There is a recognized tendency for managers to collect seeds for nursery tree production from trees that are easy to access, such as single trees in agricultural fields or next to roads. Because these data show 
that there is a greater likelihood that seeds from single trees will be produced through self-fertilization, and we cannot rule out the possibility that there is selection against inbred seeds at the seedling establishment phase, the precautionary guidance for managers would be to limit, or avoid, collecting seeds from single trees.

Seedling establishment was only observed at two study sites, one seedling at the Reserva Nacional Los Queules, and 99 seedlings at Quiles Alto. Eriksson's (1993) review found that for $60 \%$ of vegetatively-reproducing species, no seedling recruitment was observed in adult patches, even when seeds were available. The site (Quiles Alto) where the majority of seedlings were found is one of only three study sites where no clone groups were observed. However, seed production was observed at all study sites, implying factors other than seed production may limit seedling establishment at the majority of sites. It is possible that current environmental conditions at the other study sites are not suited to germination and survival and so, through habitat filtering, even when viable seeds are present they may not establish successfully (e.g. Nathan and Muller-Landau 2000). However, because all but one of the seedlings were found at Quiles Alto, the data is not available to investigate this possibility. Experiments involving planting seedlings in sites differing in habitat characteristics would help determine whether habitat filtering may be an important driver in seedling germination and establishment for this species. As has been frequently observed, the study of rare species is essential for their conservation, but their very rarity may compromise the assembly of the large data sets necessary to conclusively answer conservation questions.

There is a third possible explanation for the observed pattern of seedling establishment; G. keule could be an example of a 'seed dispersal anachronism'. Although many plant species are consumed and dispersed by a variety of primary and secondary dispersers, some plant species show the peculiar pattern of producing large numbers of apparently animalattractive fruit, but the seeds are not consumed, and so there is little or no seed dispersal or seedling establishment (Jordano et al. 2003). Janzen and Martin (1982) suggests that some still-extant plant species show combinations of fruit traits that are adapted to dispersal by now-extinct dispersal agents, calling them 'seed dispersal anachronisms'. One of the seed dispersal anachronism syndromes, the megafaunal syndrome, includes fruits that appear to have been dispersed by now extinct Pleistocene megafauna (Guimarães Jr. et al. 2008). Although seeds that fit the description of having a megafaunal seed dispersal anachronism are found globally (Guimarães Jr. et al. 2008), South America is expected to have a disproportionate number, as 59 species of South American megafauna, including all megaherbivores, went extinct during the Late Pleistocene and Early Holocene (Doughty et al. 2016).
Gomortega keule's fruits fit closely to Janzen and Martin (1982) description of megafaunal-dispersed fruit. They have large seeds protected by a hard endocarp (Fig. 1), and the fruit is indehiscent with a nutrient-rich pulp (Stern 1955). They show phenological segregation of ripening times throughout the year (Lander et al. 2009), with fruits falling to the ground upon ripening, where a large proportion of the crop rots without being consumed. Gomortega keule also fits Guimarães Jr. et al. (2008) definition of Pleistocene megafaunal-dependent fruits: fleshy fruits $4-10 \mathrm{~cm}$ diameter with up to five large seeds (generally $>2.0 \mathrm{~cm}$ diameter). Many of the plant species that fit the 'seed dispersal anachronism' syndrome appear not to have effective replacement dispersers, meaning that dispersal may be restricted, while fruits and seeds succumb more frequently to pathogen attack (Guimarães Jr. et al. 2008). These species may be especially vulnerable to habitat fragmentation and environmental change, as they have lost the ability to disperse effectively and maintain resilient meta-populations. However, MiceliMèndez et al. (2008) suggests that for some of these species, cattle may be able to disperse the fruit and seeds, offering a replacement for the extinct disperser(s). As far as we are aware, cattle are the only large frugivores in the study area, and Quiles Alto is the only study site where cattle are regularly grazed. Thus, the presence of seedlings at Quiles Alto may be linked to seed ingestion and dispersal by cattle (see also Muñoz-Concha et al. 2017). This hypothesis is supported by the fact that we found a mean dispersal distance of $9.5 \pm 10.6 \mathrm{~m}$ which is further than would be expected by gravity alone, and there was a distinct spatially-aggregated pattern of seedling establishment typical of frugivore dispersal (Garcia et al. 2007). The evidence for cattle dispersal of G. keule is circumstantial, and merits further investigation.

The lack of seedling establishment at most of the study sites means G. keule is not able to use seed dispersal and seedling establishment to maintain a functioning metapopulation, or to establish in un-colonized sites. In addition, because $G$. keule appears to reproduce vegetatively by root-sprouting rather than shoot-rooting, the species is also unlikely to disperse into new sites via vegetative propagules (Bond and Midgley 2001). This may pose a problem for $G$. keule as establishing and maintaining a meta-population is important for species persistence in landscapes experiencing on-going habitat loss (Bond and Midgley 2001).

In summary, vegetative reproduction is currently the main means of reproduction for G. keule. This reproductive strategy, although effective for in situ persistence, does not allow the species to maintain a meta-population or occupy new sites. Moreover, the lack of genetic recombination to support evolution and adaptation are critical considerations for the conservation of this species in view of on-going environmental change (Bond and Midgley 2001). Gomortega keule does produce viable seed, but only occasionally does 
this result in seedling establishment. The lack of seedling establishment at most sites appears to represent a significant barrier to G. keule's long-term survival. However, it should be noted that these data represent a snap-shot in the lifetime of long-lived individuals, and the current lack of seedlings does not necessarily indicate a total lack of seedling establishment over the lifetime of the adult individuals. Given the longevity of individual G. keule genets, rare seedling recruitment may be sufficient to maintain levels of genetic diversity (Douhovnikoff et al. 2004).

\section{Conclusions and conservation implications}

Understanding how habitat loss and fragmentation, and associated loss or changes in dispersal agents, affect seed dispersal and establishment is key to developing effective conservation and management strategies (Dirzo et al. 2014). Specific recommendations arising from this study are to increase the resilience of $G$. keule populations by: (i) enhancement planting at sites with very small populations; (ii) artificially establishing new populations in neighboring native forest fragments where the species is not currently present; and (iii) encouraging its use as a shade tree, in hedgerows, and in living fences on agricultural land to further expand the effective population size. Artificially established and enhanced populations are likely to contribute to landscape level gene flow (Lander et al. 2010; Ralls et al. 2018), and provide insurance against extinction by local extirpation. Any tree nursery program for the species must ensure that seeds are collected from a large number of trees, and limit the use of seeds from single trees which show higher rates of self-fertilization, because the impact of self-fertilization on seedling and adult growth and survival is unknown. The role of cattle in promoting seedling recruitment has not been confirmed, but we suggest that this is an avenue that merits further investigation. However, even if cattle contribute to the establishment of G. keule seedlings, the damage they can cause to other native species means we cannot recommend introducing cattle to forest sites. To improve germination and establishment in tree nursery settings, it may be worth considering processing seeds by feeding fruits to cattle or other herbivores. Finally, careful protection of existing $G$. keule populations is already required under the species' National Monument status (Ministerio de Agricultura 1995), and will be essential to the species' long-term success.

The reproductive characteristics of $G$. keule are not unique. Vegetative reproduction of woody plants is common in both temperate and tropical forests (Bond and Midgley 2001), the transition from outcross- to self-fertilization is among the most common evolutionary trends in flowering plants (Stebbins 1970), and anachronistic seed dispersal systems appear to occur worldwide (Guimarães Jr. et al. 2008). Increased understanding of the modes of reproduction by $G$. keule will contribute to management decisions for the conservation and restoration of this species and its ecological associates. We suggest that, in general, analyses to develop a full understanding of a plant species' reproductive systems, in relation to their landscape context, provide essential empirical foundations for development of effective genetic conservation strategies.

Acknowledgements We are grateful to the Comité Nacional Pro Defensa de la Flora y Fauna (CODEFF), Ministerio del Medio Ambiente (MMA), Universidad de Talca, in particular Dr. José San Martín Acevedo, Corporación Nacional Forestal (CONAF), in particular Fernando Campos-Soto, Forestal Mininco, Forestal Celco and Forestal Masisa. This study was funded by The Darwin Initiative (DEFRA) Grant Ref: 15-023 and The Genetics Society. TAL was funded by the Leverhulme Trust.

\section{Compliance with ethical standards}

Conflict of interest The authors declare that they have no conflict of interest.

Open Access This article is distributed under the terms of the Creative Commons Attribution 4.0 International License (http://creativeco mmons.org/licenses/by/4.0/), which permits unrestricted use, distribution, and reproduction in any medium, provided you give appropriate credit to the original author(s) and the source, provide a link to the Creative Commons license, and indicate if changes were made.

\section{References}

Altamirano A, Lara A (2010) Deforestation in temperate ecosystems of pre-Andean range of south-central Chile. BOSQUE 31:53-64

Archie JW (1985) Statistical analysis of heterozygosity data: independent sample comparisons. Evolution 39:623-637

Aronne G (2017) Identification of bottlenecks in the plant life cycle for sustainable conservation of rare and endangered species. Front Ecol Evol 5:76. https://doi.org/10.3389/fevo.2017.00076

Bacles CFE, Lowe A, Ennos RA (2006) Effective seed dispersal across a fragmented landscape. Science 311:628

Baddeley A, Rubak E, Turner R (2015) Spatial point patterns: methodology and applications with R. Chapman and Hall/CRC Press, London

Bellingham PJ (2000) Resprouting as a life history strategy in woody plant communities. Oikos 89:409-416

Bond WJ, Midgley JJ (2001) Ecology of sprouting in woody plants: the persistence niche. Trends Ecol Evol 16:45-51

Brooks TM et al (2002) Habitat loss and extinction in the hotspots of biodiversity. Conserv Biol 16:909-923

Brudvig LA, Damschen EI, Haddad NM, Levey DJ, Tewksbury JJ (2015) The influence of habitat fragmentation on multiple plantanimal interactions and plant reproduction. Ecology 96:26692678. https://doi.org/10.1890/14-2275.1

Burczyk J, Adams W, Shimizu J (1996) Mating patterns and pollen dispersal in a natural knobcone pine (Pinus attenuata Lemmon) stand. Heredity 77:251-260 
Byrne M, Elliott CP, Yates C, Coates DJ (2007) Extensive pollen dispersal in a bird-pollinated shrub, Calothamnus quadrifidus, in a fragmented landscape. Mol Ecol 16:1303-1314. https://doi. org/10.1111/j.1365-294X.2006.03204.x

Cain ML, Milligan BG, Strand AE (2000) Long-distance seed dispersal in plant populations. Am J Bot 87:1217-1227

Carrió E, Jiménez JF, Sánchez-Gómez P, Güemesa J (2009) Reproductive biology and conservation implications of three endangered snapdragon species (Antirrhinum, Plantaginaceae). Biol Cons 142:1854-1863

Cheptou P-O, Hargreaves A, Bonte D, Jacquemyn H (2017) Adaptation to fragmentation: evolutionary dynamics driven by human influences. Phil Trans R Soc B 372:20160037. https://doi.org/10.1098/ rstb.2016.0037

Damschen EI et al (2014) How fragmentation and corridors affect wind dynamics and seed dispersal in open habitats. Proc Natl Acad Sci USA 111:3484-3489. https://doi.org/10.1073/pnas.1308968111

Dirzo R, Young HS, Galetti M, Ceballos G, Isaac NJB, Collen B (2014) Defaunation in the Anthropocene. Science 345:401-406

Doughty CE, Faurby S, Svenning J-C (2016) The impact of the megafauna extinctions on savanna woody cover in South America. Ecography 39:213-222

Douhovnikoff V, Cheng AM, Dodd RS (2004) Incidence, size and spatial structure of clones in second-growth stands of coast redwood, Sequoia sempervirens (Cupressaceae). Am J Bot 91:1140-1146

Eckert C (2002) The loss of sex in clonal plants. Evol Ecol 15:501-520

Eriksson O (1993) Dynamics of genets in clonal plants. Trends Ecol Evol 8:313-316

Evans MEK, Menges ES, Gordon DR (2003) Reproductive biology of three sympatric endangered plants endemic to Florida scrub. Biol Cons 111:235-246

Franceschinelli EV, Bawa KS (2000) The effect of ecological factors on the mating system of a South American shrub species (Helicteres brevispira). Heredity 84:116-123

Garcia C, Jordano P, Godoy JA (2007) Contemporary pollen and seed dispersal in a Prunus mahaleb population: patterns in distance and direction. Mol Ecol 16:1947-1955

Goldblatt P (1976) Chromosome number in Gomortega keule. Ann MO Bot Gard 63:207-208

González M (1998) Gomortega keule. The IUCN Red List of Threatened Species. IUCN, https://www.iucnredlist.org/species/31357 19628984

Guimarães P Jr, Galetti M, Jordano P (2008) Seed dispersal anachronisms: rethinking the fruits extinct megafauna Ate. PLoS ONE 3:e1745. https://doi.org/10.1371/journal.pone.0001745

Hanski I (1998) Metapopulation dynamics. Nature 396:41-49

Hardesty BD, Hubbell SP, Bermingham E (2006) Genetic evidence of frequent long-distance recruitment in a vertebratedispersed tree. Ecol Lett 9:516-525. https://doi.org/10.111 1/j.1461-0248.2006.00897.x

Hechenleitner P, Gardner MF, Thomas PI, Echeverría C, Escobar B, Brownless P, Martinez CA (2005) Plantas Amenazadas del Centro-Sur de Chile Distribución, Conservación y Propagación. Universidad Austral de chile y Real Jardin Botanico de Edimburgo, Valdivia

Herrera JM, Garcia D (2010) Effects of forest fragmentation on seed dispersal and seedling establishment in ornithochorous trees. Conserv Biol 24:1089-1098. https://doi.org/10.111 1/j.1523-1739.2010.01459.x

Husband BC, Schemske DW (1996) Evolution of the magnitude and timing of inbreeding depression in plants. Evolution 50:54-70

IUCN (2012) IUCN red list categories and criteria: version 3.1, 2nd edn. IUCN, Gland, Cambridge

Janzen DH, Martin PS (1982) Neotropical anachronisms-the fruits the gomphotheres ate. Science 215:19-27
Jordano P, Bascompte J, Olesen J (2003) Invariant properties in coevolutionary networks of plant-animal interactions. Ecol Lett 6:69-81

Kalinowski ST, Taper ML, Marshall TC (2007) Revising how the computer program CERVUS accommodates genotyping error increases success in paternity assignment. Mol Ecol 16:10991106. https://doi.org/10.1111/j.1365-294X.2007.03089.x

Lander TA, Boshier DH, Harris SA (2007) Isolation and characterization of eight polymorphic microsatellite loci for the endangered, endemic Chilean tree Gomortega keule (Gomortegaceae). Mol Ecol Notes 7:1332-1334

Lander TA, Harris SA, Boshier DH (2009) Flower and fruit production and insect pollination of the endangered Chilean tree Gomortega keule in native forest, exotic pine plantation and agricultural environments Revista Chilena De Historia. Natural 82:403-412

Lander TA, Boshier DH, Harris SA (2010) Fragmented but not isolated: contribution of single trees, small patches and long-distance pollen flow to genetic connectivity for Gomortega keule, an endangered Chilean tree. Biol Conserv 143:2583-2590. https ://doi.org/10.1016/j.biocon.2010.06.028

Lenormand T (2002) Gene flow and the limits to natural selection. Trends Ecol Evol 17:183-189

Lewis P, Zaykin D (2002) GDA for Windows, release 1.1. Departement of Ecology and Evolutionary Biology, The University of Connecticut, Storrs

Lloyd DG (1992) Self- and cross-fertilization in plants. II The selection of self-fertilization. Int J Plant Sci 153:370-380

Lowe AJ, Boshier D, Ward M, Bacles CFE, Navarro C (2005) Genetic resource impacts of habitat loss and degradation; reconciling empirical evidence and predicted theory for neotropical trees. Heredity 95:255-273

Lowe A, Cavers S, Boshier D, Breed M, Hollingsworth P (2015) The resilience of forest fragmentation genetics-no longer a paradox-we were just looking in the wrong place. Heredity 115:9799. https://doi.org/10.1038/hdy.2015.40

Miceli-Mèndez CL, Ferguson BG, Ramìrez-Marcial N (2008) Seed dispersal by cattle: natural history and applications to neotropical forest restoration and agroforestry. In: Myster RW (ed) Postagricultural succession in the neotropics. Springer-Verlag, New York, pp 165-191

Ministerio de Agricultura (1995) Declara monumento natural las especies forestales Queule, Pitao, Belloto del Sur, Belloto del Norte y Ruil. Decreto Supremo 13 de 1995. Chile

Muñoz-Concha D, Davey MR, Ribas G, Mayes S (2017) Microsatellite analysis of populations of the endangered tree Gomortega keule suggests pre-Columbian differentiation. N Zeal J Bot 55:318-333

Myers N (1990) The biodiversity challenge: expanded hot-spots analysis. Environmentalist 10:243-256

Myers N, Mittermeier RA, Mittermeier CG, Fonseca GABD, Kent J (2000) Biodiversity hotspots for conservation priorities. Nature 403:853-858

Nathan R, Muller-Landau HC (2000) Spatial patterns of seed dispersal, their determinants and consequences for recruitment. Trends Ecol Evolution 15:278-285

Niinemets U (2007) Photosynthesis and resource distribution through plant canopies. Plant Cell Environ 30:1052-1071. https://doi.org /10.1111/j.1365-3040.2007.01683.x

Oldfield S, Lusty C, MacKinven A (1998) The World List of Threatened Trees. World Conservation Press, Cambridge

Oosterhout CV, Hutchinson WF, Wills DPM, Shipley P (2004) MICRO-CHECKER: software for identifying and correcting genotyping errors in microsatellite data. Mol Ecol Notes 4:535-538. https://doi.org/10.1111/j.1471-8286.2004.00684.x

Peakall R, Smouse PE (2006) GENALEX 6: genetic analysis in excel population genetic software for teaching and 
research. Mol Ecol Notes 6:288-295. https://doi.org/10.111 1/j.1471-8286.2005.01155.x

Pereira HM, Daily GC, Roughgarden J (2004) A framework for assessing the relative vulnerability of species to land-use change. Ecol Appl 14:730-742

Pinheiro J, Bates D, DebRoy S, Sarkar D, R Core Team (2018) nlme: Linear and Nonlinear Mixed Effects Models. R package version 3.1-137. https://CRAN.R-project.org/package=nlme

Ralls K et al (2018) Call for a paradigm shift in the genetic management of fragmented populations. Conserv Lett 11:e12412

Reed DH, Frankham R (2003) Correlation between fitness and genetic diversity. Conserv Biol 17:230-237

Ritland K (2002) Extensions of models for the estimation of mating systems using $\mathrm{n}$ independent loci. Heredity $88: 221-228$

Rymer P, Sandiford M, Harris S, Billingham M, Boshier D (2015) Remnant Pachira quinata pasture trees have greater opportunities to self and suffer reduced reproductive success due to inbreeding depression. Heredity 115:115-124

San Martín J, Donoso C (1995) Floristic structure and human impact on the Maulino forest of Chile. In: Armesto JJ, Villagrán C, Arroyo MK (eds) Ecología de los bosques nativos de Chile. Editorial Universitaria, Santiago, pp 153-167

San Martin J, Sanchez A (1999) Las Comunidades Relictas de Gomortega keule (Gomortegaceae, Magnoliopsia) en Chile Central. Anales Jardin Botanico de Madrid 57:317-326

Schulz JJ, Cayuela L, Echeverria C, Salas J, Benayasa JMR (2010) Monitoring land cover change of the dryland forest landscape of Central Chile (1975-2008). Appl Geogr 30:436-447. https://doi. org/10.1016/j.apgeog.2009.12.003

Schurr FM, Midgley GF, Rebelo AG, Reeves G, Poschlod P, Higgins SI (2007) Colonization and persistence ability explain the extent to which plant species fill their potential range. Glob Ecol Biogeogr $16: 449-459$

Soltis P, Soltis D (2004) The origin and deversification of angiosperms. Am J Bot 91:1614-1626

Sork VL, Davis FW, Smouse PE, Apsit VJ, Dyer RJ, Fernandez JF, Kuhn B (2002) Pollen movement in declining populations of California Valley oak, Quercus lobata: where have all the fathers gone? Mol Ecol 11:1657-1668

Stebbins GL (1970) Adaptive radiation in angiosperms. I Pollination mechanisms. Ann Rev Ecol System 1:307-326
Stern WL (1955) Xylem anatomy and relationships of gomortegaceae. Am J Bot 42:874-885

Synnott TJ (1979) A manual of permanent plot procedure for tropical rainforests. Commonwealth Forestry Institute, University of Oxford, Oxford

Tigano A, Friesen VL (2016) Genomics of local adaptation with gene flow. Mol Ecol 25:2144-2164. https://doi.org/10.1111/mec.13606

van Kleunen M, Fischer M, Schmid B (2001) Effects of intraspecific competition on size variation and reproductive allocation in a clonal plant. Oikos 94:515-524

Venables WN, Ripley BD (2002) Modern applied statistics with S, 4th edn. Springer, New York

Villegas P, le Quesne C, Lusk CH (2003) Structure and dynamics of a population of Gomortega Keule (Mol.) baillon in old growth valdivian rain forest in south-central Chile. Gayana Botanica 60:107-113

Vranckx G, Jacquemyn H, Muys B, Honnay O (2012) Meta-analysis of susceptibility of woody plants to loss of genetic diversity through habitat fragmentation. Conserv Biol 26:228-237. https://doi.org/ 10.1111/j.1523-1739.2011.01778.x

White GM, Boshier D, Powell W (2002) Increased pollen flow counteracts fragmentation in a tropical dry forest: an example from Swietenia humilis Zuccarini. Proc Natl Acad Sci USA 99:2038-2042

Wright S, Ness R, Foxe J, Barrett S (2008) Genomic consequences of outcrossing and selfing in plants. Int J Plant Sci 169:105-118

Young A, Boyle T, Brown T (1996) The population genetic consequences of habitat fragmentation for plants. Trends Ecol Evol 11:413-418

Zeigler SL, Che-Castaldo JP, Neel MC (2013) Actual and potential use of population viabilityanalyses in recovery of plant species listed under the U.S. Endangered Species Act. Conserv Biol 27:1265-1278

Publisher's Note Springer Nature remains neutral with regard to jurisdictional claims in published maps and institutional affiliations. 